\title{
Dairy cow breed interacts with stocking rate in temperate pasture-based dairy production systems ${ }^{1}$
}

\author{
O. K. Spaans, ${ }^{*} \dagger$ K. A. Macdonald, ${ }^{*}$ J. A. S. Lancaster, ${ }^{*}$ A. M. Bryant, ${ }^{*}$ and J. R. Roche ${ }^{*} \ddagger^{2}$ \\ *DairyNZ, Private Bag 3221, Hamilton 3240, New Zealand \\ †Department of Biological Sciences, University of Waikato, Hamilton 3210, New Zealand \\ $\ddagger$ School of Biological Sciences, University of Auckland, Private Bag 92019, Auckland 1142, New Zealand
}

\begin{abstract}
Economic optimum stocking rates for grazing dairy systems have been defined by accounting for the pasture production potential of the farm [ $\mathrm{t}$ of dry matter $(\mathrm{DM}) / \mathrm{ha}$ ], the amount of feed imported from outside the farm ( $\mathrm{t}$ of $\mathrm{DM} / \mathrm{ha})$, and the size of the cow $(\mathrm{kg})$. These variables were combined into the comparative stocking rate $[\mathrm{CSR} ; \mathrm{kg}$ of body weight $(\mathrm{BW}) / \mathrm{t}$ of feed DM available] measure. However, CSR assumes no effect of cow genetics beyond $\mathrm{BW}$, and there is increasing evidence of within-breed differences in residual feed intake and between-breed differences in the gross efficiency with which cows use metabolizable energy for milk production. A multiyear production system experiment was established to determine whether Jersey $(\mathrm{J})$ and Holstein-Friesian (HF) breeds performed similarly at the same CSR. Fifty-nine J cows and $51 \mathrm{HF}$ cows were randomly allocated to 1 of 2 CSR in a $2 \times$ 2 factorial arrangement; systems were designed to have a CSR of either 80 or $100 \mathrm{~kg}$ of BW/t of feed DM (JCSR80, J-CSR100, HF-CSR80, and HF-CSR100 treatment groups). Data were analyzed for consistency of farmlet response over years using ANOVA procedures, with year and farmlet as fixed effects and the interaction of farmlet with year as a random effect. The collated biological data and financial data extracted from a national economic database were used to model the financial performance for the different breed and CSR treatments. On average, annual and individual season pasture DM production was greater for the $\mathrm{J}$ farmlets and was less in the CSR100 treatment; however, the effect of CSR was primarily driven by a large decline in pasture DM production in the HF-CSR100 treatment (breed $\times$ CSR interaction). This interaction in
\end{abstract}

\footnotetext{
Received October 22, 2017.

Accepted January 20, 2018.

${ }^{1}$ The reproduction results from 1 yr of data from the current study were presented previously in conference proceedings (McDougall et al., 1995).

${ }^{2}$ Corresponding author: john.roche@dairynz.co.nz
}

feed availability resulted in a breed $\times$ CSR interaction for the per-cow and per-hectare milk production variables, with HF cows producing more milk and milk components per cow in the CSR 80 treatment but the same amount as the J cows in the CSR100 treatment. On a per-hectare basis, HF cows produced the same amount of $4 \%$ fat-corrected milk and lactose as J cows in the CSR80 treatment, but less fat; at CSR100, J cows produced more $4 \%$ fat-corrected milk, fat, and protein per hectare than HF cows. Our results support a greater gross efficiency for use of metabolizable energy by the $\mathrm{J}$ cow; $11 \%$ less total metabolizable energy was required to produce $1 \mathrm{~kg}$ of fat and protein at a system level. Economic modeling indicated that profitability of both breeds was less at CSR100, but the decline in profitability with increasing stocking rate was much greater in the HF breed. Holstein-Friesian cows were more profitable at CSR80 but were less profitable at CSR100.

Key words: grazing, economics, energy-use efficiency

\section{INTRODUCTION}

There is irrefutable evidence that animal agriculture has increased in resource-use efficiency over the last 75 yr (Macdonald et al., 2008b; Capper et al., 2009; Roche et al., 2017a). Nevertheless, the requirement for food is predicted to increase by a further 75 to $100 \%$ over the next 35 yr (FAO, 2009; Godfray et al., 2010); this will increase the pressure on food production systems to become even more efficient. A significant portion of the historical increase in efficiency was a result of genetic selection for production-related traits. For example, Capper et al. (2009) reported that only $21 \%$ of cows are required today compared with 1944 to produce the same volume of milk. Similarly, Macdonald et al. (2008b) reported that genetic improvements within the Holstein-Friesian (HF) breed resulted in a $16 \%$ increase in milk yield, a $21 \%$ increase in milk fat production, and a 26\% increase in milk protein between 1970 and 2000 , with only a $2 \%$ increase in maintenance requirements. This improvement in production efficiency is 
particularly important in temperate grazing systems, as cow DMI is limited by time to graze and not the physical capacity of the cow (Sheahan et al., 2011).

Cow breed has also been reported to affect feed conversion efficiency (FCE) in grazing systems. For example, Prendiville et al. (2009) reported that Jersey (J) cows required 7 to $8 \%$ less total feed for every kilogram of milk fat and protein produced in a pasture-based dairy production system compared with HF cows. This is consistent with the reported differences in the mass of the gastrointestinal tract (i.e., $24 \%$ lighter in J cows; Beecher et al., 2014), a 2 to $3 \%$ greater digestibility of DM and NDF by J cows (Beecher et al., 2014), and the greater use of consumed ME for productive purposes by the J cow (L'Huillier et al., 1988) compared with HF cows. The improvement in the efficiency of ME use, however, was apparent only in a grazing environment with restricted DMI, where J cows produced $20 \%$ more milk/kg of DMI (L'Huillier et al., 1988); under ad libitum feeding, this ME conversion gain disappeared. This genetics $\times$ environment interaction was also reported by Bryant et al. (2006) when they identified that the milk production superiority of $\mathrm{HF}$ cows over $\mathrm{J}$ cows was greater in higher milk production environments, an indicator of higher feed allowances.

Based on their superior FCE, it would appear that in grazing systems, where DMI limits production (Kolver and Muller, 1998), the J may have a production efficiency advantage over HF due to their smaller size and less total maintenance requirement per cow. In almost all comparisons, however, the $\mathrm{J}$ cows produced less milk. Therefore, more $\mathrm{J}$ cows would be required for the equivalent per-hectare milk production of the HF. As between 50 and $60 \%$ of costs in a grazing system are associated with individual cows (Macdonald et al., 2011), having more J cows to produce the same volume of milk may negatively affect farm profitability, even if a greater proportion of consumed ME is partitioned to milk production. Nevertheless, the reported interaction between breed and FCE (L'Huillier et al., 1988) might indicate an advantage for $\mathrm{J}$ cows in farming systems that limit feed allowance per cow (e.g., high stocking rate; Macdonald et al., 2008a) and HF cows in production systems that provide a greater feed allowance per cow. To test this hypothesis, J and HF cows were compared in pasture-based systems over multiple lactations at either moderate or high stocking rates.

\section{MATERIALS AND METHODS}

The experiment was conducted over 3 lactations at No. 2 Dairy, DairyNZ (Hamilton, New Zealand; $37^{\circ} 47^{\prime}$ S, $175^{\circ} 19^{\prime} \mathrm{E}, 40 \mathrm{~m}$ above sea level), between 1990 and 1993. However, based on recent component-study publications, it was deemed that the data were sufficiently relevant and important to present in a scientific journal. The permanent grassland area had pastures of predominantly ryegrass (Lolium perenne L.) and white clover (Trifolium repens L.), with evenly distributed soil type, specifically a Te Rapa peaty silt loam soil (known as a Humic Aquic Haplorthod in soil taxonomy or a Humose Groundwater-Gley Podzol in the New Zealand classification).

\section{Experimental Design and Treatments}

Fifty-nine J cows and $51 \mathrm{HF}$ cows were randomly allocated to 1 of 2 comparative stocking rates (CSR; calculated as $\mathrm{kg}$ of $\mathrm{BW} / \mathrm{t}$ of feed DM allowance; Macdonald et al., 2008a) in a $2 \times 2$ factorial arrangement; systems were designed to have a CSR of either 80 or $100 \mathrm{~kg}$ of $\mathrm{BW} / \mathrm{t}$ of feed DM. This resulted in the $\mathbf{J}$ CSR80, J-CSR100, HF-CSR80, and HF-CSR100 treatment groups. Comparative stocking rate is a more complete measure of stocking rate than feed allowance per cow because it accounts for the number of cows per hectare (i.e., stocking rate), the BW of the cow (i.e., as a proxy for milk production potential), the pasture producing potential of the farm ( $t$ of pasture $\mathrm{DM} / \mathrm{ha}$ ), the amount of supplement imported from off the farm ( $t$ of $\mathrm{DM} / \mathrm{ha}$ ), and whether replacement stock are reared on the farm or on land remote from the milking platform (Macdonald et al., 2008a). From a profitability perspective, optimum CSR for grazing dairy systems with HF cows was reported to be 75 to $80 \mathrm{~kg}$ of $\mathrm{BW} / \mathrm{t}$ of feed DM (Macdonald et al., 2011). Because of the different $\mathrm{BW}$ of $\mathrm{J}$ and $\mathrm{HF}$ cows, the number of cows was greater in the $\mathrm{J}$ treatment to ensure the same CSR as the HF treatment.

Historically, average pasture production on the experimental farm was $16.5 \mathrm{t}$ of $\mathrm{DM} / \mathrm{ha}$ (Macdonald et al., 2017) and cow BW was 360 and $420 \mathrm{~kg}$ of BW for $\mathrm{J}$ and HF cows, respectively (mid-lactation BW). To create the 80 and $100 \mathrm{~kg}$ of $\mathrm{BW} / \mathrm{t}$ of feed DM CSR treatments for both breeds, J cows were managed at stocking rates of 3.6 and 4.5 cows/ha (26 and 33 cows, respectively), and HF cows were managed at 3.0 and 4.0 cows/ha (22 and 29 cows, respectively). This equated to $1,285,1,631,1,268$, and $1,670 \mathrm{~kg}$ of $\mathrm{BW} / \mathrm{ha}$ for the J-CSR80, J-CSR100, HF-CSR80, and HF-CSR100 treatment groups, respectively, and an expected feed allowance of $4.6 \mathrm{t}$ of DM, $3.7 \mathrm{t}$ of DM, $5.5 \mathrm{t}$ of DM, and $4.1 \mathrm{t}$ of pasture DM/cow in each of the 4 treatments, respectively.

The cows were selected from the research farm herd so that the genetic merit of the breeds was as similar as possible. Estimated breeding values and the genetic merit of the cows were recalculated in the most re- 
cent genetic evaluation (NZ Animal Evaluation Ltd., Hamilton, New Zealand, data); EBV for volume, fat, protein, BCS (10-point scale; Roche et al., 2004), fertility, residual survival, BW, SCC, and gestation length for $\mathrm{HF}$ and J cows, respectively, were +192 and -952 $\mathrm{kg},-0.3$ and $-13.1 \mathrm{~kg},-3.4$ and $-25.5 \mathrm{~kg},+0.17$ and +0.04 BCS units, +2.9 and $+2.2,+43$ and $-18 \mathrm{~d},+39$ and $-65 \mathrm{~kg},-0.21$ and -0.19 , and +1.9 and $+2.9 \mathrm{~d}$. Breeding worth (i.e., national measure of genetic merit for profit) was $-\$ 43.50$ and $-\$ 2.10$ for the HF and J cows, respectively.

Seventy-two 0.4-ha paddocks were randomly allocated to 1 of 4 farmlets, ensuring that paddock allocation was balanced for geographic location, soil type, distance from the milking parlor, and previous experimental treatments. As such, farmlets were evenly spread over the farm in a checkerboard fashion (Macdonald et al., 2008a). Each farmlet was then randomly allocated to 1 of the 4 treatments. Once farmlets were established, they were unchanged throughout the trial.

\section{Trial Management}

Grazing and Fertilizer Management. Grazing management was determined by monitoring farm pasture cover on a weekly basis. Each herd was allocated fresh pasture once daily, as described by Macdonald et al. (2008a), and returned to the same area only when a minimum of 2 leaves were present on the majority $(>66 \%)$ of perennial ryegrass tillers. For all stocking rates, the intended postgrazing residual height was 40 $\mathrm{mm}$.

For the J-CSR80, J-CSR100, HF-CSR80, and HFCSR100 herds, respectively, the average number of days in their intergrazing interval (i.e., rotation length) was as follows: winter, $72 \pm 27.5,74 \pm 26.6,72 \pm 27.6$, and $73 \pm 26.6$; spring, $19 \pm 2.7,20 \pm 3.6,19 \pm 2.7$, and 20 \pm 3.6 ; summer, $19 \pm 3.0,20 \pm 6.0,19 \pm 3.0$, and 20 \pm 6.0 ; and autumn, $47 \pm 26.8,58 \pm 30.5,43 \pm 26.2$, and $58 \pm 30.5$. Surplus pasture was conserved as silage when growth rate exceeded herd requirements; on average, 222 and $205 \mathrm{~kg}$ of pasture silage DM/cow was harvested on the J-CSR80 and HF-CSR80 farmlets, respectively; no silage was conserved on the CSR100 farmlets. Pasture was sampled for DM content before baling, and the bales were weighed from each paddock to give an estimate of the amount of feed conserved. Mechanical cutting (i.e., clipping or topping) of residual pasture postgrazing was applied as deemed necessary to maintain quality. All farmlets received $54 \mathrm{~kg}$ of $\mathrm{P} / \mathrm{ha}$ and $55 \mathrm{~kg}$ of $\mathrm{S} / \mathrm{ha}$ as single superphosphate and $50 \mathrm{~kg}$ of $\mathrm{K} / \mathrm{ha}$ as muriate of potash. No nitrogen fertilizer was applied. When pasture silage was harvested, an additional $50 \mathrm{~kg}$ of $\mathrm{K} / \mathrm{ha}$ was applied to the relevant area.
Animal Management. Across the farmlets, all cows were managed in a similar manner to what has been described previously for multiyear farm system experiments (Horan et al., 2005; Macdonald et al., 2008a). The system of milk production was seasonal, with the median calving dates across all years being within 1 wk (July 26-July 31); approximately 50\% of cows calved within 2 wk of planned start of calving (mid to late July), $40 \%$ calved in the next 4 wk (August), and the remaining cows calved during wk 7 and 8 (early September; Roche et al., 2017b). Cows with a calving due date later than wk 8 of the calving period were induced to calve during wk 7 or 8 with the 2 -step use of the hormones dexamethasone (Opticortenol S, Novartis Animal Health, Basel, Switzerland; Voren, Boehringer-Ingelheim, Berkshire, UK) and prostaglandin (Estrumate, Schering-Plough Coopers, Kenilworth, NJ). This procedure was performed only if cows had low SCC before dry-off $(<200,000$ cells $/ \mathrm{mL})$, had a BCS of $\geq 5.0$ (on a 10-point scale; Roche et al., 2004), and had blood $\mathrm{Mg}$ of $>0.8 \mathrm{mmol} / \mathrm{L}$ and $\gamma$-glutamyl transferase of 15 to $22 \mathrm{U} / \mathrm{L}$ of plasma.

The routine mating management policy at No. 2 Dairy was to record any cows exhibiting signs of estrus before the planned start of the seasonal breeding period. Estrus detection was performed by twice-daily visual observation of estrous behavior with the aid of paint applied to the tail-head of the cow (i.e., chalking or tail painting). Cows not detected in estrus by the planned start of the seasonal breeding period were presented for veterinary examination. Those without a palpable corpus luteum were treated with an intravaginal controlled internal drug-releasing insert (InterAg, Hamilton, New Zealand) per the Genermate program (Cliff et al., 1995). Artificial insemination was performed for the first 6 wk of the seasonal breeding period followed by a further 6 wk of natural breeding with a Hereford bull. Pregnancy diagnosis was performed by manual palpation of uterine contents at least 5 wk after the end of the 12 -wk breeding period.

At the end of each lactation, approximately $20 \%$ of the cows from each farmlet were culled because of reproductive failure, health, age, and genetic merit and were replaced with primiparous cows 1 mo before the planned start of calving. Age structure did not differ across farmlets for the duration of the study. Lactation length was shortened for individual cows within each season based on individual cow BCS, level of milk production, and number of days from calving (Macdonald and Penno, 1998; Macdonald et al., 2008a).

Animal Health. Because of low pasture $\mathrm{Mg}(<0.2 \%$ $\mathrm{DM})$ and relatively high pasture $\mathrm{K}(>3.5 \% \mathrm{DM})$ concentrations during winter and spring, $\mathrm{Mg}$ supplementation was routinely practiced to prevent hypomagnesemia 
and associated hypocalcemia (Roche and Berry, 2006). Magnesium oxide was top dressed on pastures grazed by the nonlactating cows from 3 wk before the planned start of calving until calving was completed. After calving, all lactating cows received $20 \mathrm{~g}$ of $\mathrm{Mg} / \mathrm{d}$ as an oral supplement of magnesium chloride $\left(\mathrm{MgCl}_{2} \cdot 6 \mathrm{H}_{2} \mathrm{O}\right)$ at the a.m. milking until late November, when $\mathrm{Mg}$ supplementation ceased.

During periods of increased risk of frothy bloat, an antibloating solution (Pluronic; Ecolab, Hamilton, New Zealand) was also provided orally at the morning milking. Zinc sulfate (3.6 g of $\mathrm{ZnSO}_{4} \cdot 7 \mathrm{H}_{2} \mathrm{O} / 100 \mathrm{~kg}$ of $\left.\mathrm{BW}\right)$ was given to the cows orally during periods of increased vulnerability to facial eczema, as determined by fungal (Pithomyces chartarum) spore counts. Water troughs were in each paddock and at the dairy such that cows had unlimited access to clean drinking water.

\section{Measurements}

Pasture Measurement. Pasture mass was estimated by 2 people using calibrated visual assessment of each paddock from a weekly farm walk similar to the method described by O'Donovan et al. (2002). On each occasion, 11 calibration quadrats (each $0.3 \mathrm{~m}^{2}$ ) covering a range of pasture mass were assessed before and after the farm walk. After the final assessment, the pasture within the quadrats was cut to ground level, washed, and dried in a forced draft oven at $100^{\circ} \mathrm{C}$ until dry (approximately $48 \mathrm{~h}$ ). The pasture mass estimate for each paddock during the farm walk (for that week) was then adjusted using a regression of quadrat visual assessment on measured quadrat herbage mass. The net pasture accumulation was calculated each week from the increase in pasture mass on ungrazed paddocks. These data were used to estimate total pasture grown per hectare per year.

Grazing height was reversed calculated from equations regressing compressed pasture height (Platemeter, Farmworks, Palmerston North, New Zealand) developed for each season over $3 \mathrm{yr}$ specifically for this research farm:

- $\quad$ winter DM yield $(\mathrm{kg}$ of DM/ha $)=139.6 \times \mathrm{ht}+$ 317.5 ,

- $\quad$ spring DM yield $(\mathrm{kg}$ of DM/ha $)=124.8 \times \mathrm{ht}+$ 875.4 ,

- $\quad$ summer DM yield $(\mathrm{kg}$ of DM/ha $)=170.8 \times \mathrm{ht}+$ 1,423.6, and

- autumn DM yield $(\mathrm{kg}$ of DM $/$ ha $)=120.3 \times \mathrm{ht}$ $+952.8$

where compressed height (ht) is measured in $0.5 \mathrm{~cm}$.
In addition, to estimate pasture harvested per hectare per year, pasture mass in individual paddocks was visually assessed on $3 \mathrm{~d}$ each week pre- and postgrazing. Estimated pasture harvested ( $\mathrm{kg}$ of $\mathrm{DM} / \mathrm{cow}$ per day) was calculated from pasture disappearance by as

$$
\begin{gathered}
\text { (pregrazing DM mass - postgrazing DM mass) } \\
\times \text { area grazed per day/no. of cows. }
\end{gathered}
$$

Milk, BCS, BW, and Energy Balance Estimates. Individual cow milk yields were recorded weekly (Tru-Test milk meter system, Palmerston North, New Zealand). Milk fat, CP, and lactose concentrations were determined on composite p.m. and a.m. aliquot samples by Fossomatic FT120 (Foss Electric, Hillerød, Denmark). Milk component data were verified by reference techniques for a subset of milk samples (milk fat: Röse-Gottlieb, International Organization for Standardization, 1987; CP: macro-Kjeldahl techniques, Barbano et al., 1991).

Body weight and BCS were determined weekly during the nonlactating period (at $\sim 0900 \mathrm{~h}$ ) until approximately $12 \mathrm{wk}$ postparturition and then every other week (following the a.m. milking). Body condition score was assessed on a 10-point scale, where $1=$ emaciated and $10=$ obese (Roche et al., 2004). The ME requirements for maintenance, activity, pregnancy, BCS change, and milk production per cow and per hectare were calculated using equations presented by Primary Industries Standing Committee (2007; see Supplemental Material, https://doi.org/10.3168/jds.2017-14032).

\section{Statistical Analyses and Economic Modeling}

Data were analyzed for consistency of farmlet response to the different treatments over 3 yr by calculating means for each variable for each farmlet in each year and analyzing these using ANOVA procedures in Genstat (VSN International, Rothamsted, United Kingdom). Year and farmlet were fixed effects, and the interaction of farmlet and year was a random effect.

The economics of the breed and stocking rate comparisons were modeled using the same methodology described by Macdonald et al. (2011, 2017). Production data were averaged across years to provide 1 value per farmlet. The percentage of stock replaced each year $(20 \%)$ was the same across farmlets; therefore, the amount of stock available for sale increased with stocking rate. Gross revenue was calculated as the sum of milk and stock sales. The proportion of each expense category was classified as a per-cow or a per-hectare expense (Macdonald et al., 2011); the proportions are 
presented in Supplemental Table S1 (https://doi.org/ 10.3168/jds.2017-14032). Wherever expenses could be separated for individual farmlets (e.g., feed, silage conservation), actual data were used. Wherever data could not be separated for individual farmlets because of the structure of the research farm accounting system (administration, depreciation, electricity costs, repairs and maintenance, standing charges, vehicle expenses), equivalent expenses per cow and per hectare from similar farming systems were extracted from a commercial database used for measuring and benchmarking farm economic performance in New Zealand (DairyBase, DairyNZ, Hamilton, NZ; see Supplemental Table S2, https://doi.org/10.3168/jds.2017-14032; n $=87$ farms over 3 yr: 2012-2015). Additional assumptions include a milk price of $\$ 0.45 / \mathrm{kg}(\$ 4.04 / \mathrm{kg}$ of fat and $\$ 7.35 / \mathrm{kg}$ of protein; all figures in NZ\$ unless otherwise stated), a conservation cost for pasture silage made of $\$ 250 / \mathrm{t}$ of DM. These costs were accurate at the time of writing. Furthermore, at the time of writing, NZ $\$ 1$ was worth approximately US\$0.71 and €0.59.

\section{RESULTS AND DISCUSSION}

The effects of stocking rate on pasture and animal production characteristics (Macdonald et al., 2008a, 2011; McCarthy et al., 2016), nitrate leaching (McCarthy et al., 2015; Roche et al., 2016), and dairy farm profitability (Macdonald et al., 2011) in temperate pasture-based production systems have been extensively reported. These studies were exclusively undertaken on HF cows, and Macdonald et al. (2008a) assumed that the effects of stocking rate were the same for all breeds when they introduced the concept of CSR.

However, compared with J cows, many differences have been identified in production and biological characteristics in HF cows that could interact with stocking rate (L'Huillier et al., 1988; White et al., 2001, 2002; Washburn et al., 2002; Prendiville et al., 2009, 2010; Beecher et al., 2014). For example, J cows have lower maintenance requirements (Beecher et al., 2014) and were reported to require 7 to $8 \%$ less feed DM to produce $1 \mathrm{~kg}$ of fat and protein in a pasture-based system (Prendiville et al., 2009). Such characteristics would imply a possible superiority of the $\mathrm{J}$ breed's performance under a high CSR (i.e., lower feed allowance) and where lower milk yield per cow is accepted (Macdonald et al., 2008a; McCarthy et al., 2016). It is plausible, therefore, that the optimum CSR for HF cows is different from that for J cows. To test the hypothesis that an interaction exists between stocking rate and breed, we compared $\mathrm{HF}$ and J dairy cows either at the predefined optimum CSR (CSR80: 75-80 kg of BW/t of feed DM; Macdonald et al., 2011) or at CSR100 (100 kg of BW/t of feed DM available), which is a CSR $25 \%$ greater than optimum.

\section{Pasture Production}

Effects of breed, CSR, and the interaction of breed and CSR on annual and seasonal pasture production, average seasonal pasture cover (i.e., average mass of pasture on the farm; $\mathrm{kg}$ of $\mathrm{DM} / \mathrm{ha}$ ) and on the amount of pasture conserved as silage are presented in Table 1. Annual pasture production was greater $(P<0.01)$ in the $\mathrm{J}$ breed farmlet and in the CSR 80 treatment because of treatment effects during spring $(P<0.01)$, summer $(P<0.05)$, and autumn $(P<0.01)$. Because of this, average pasture cover was also greater for the $\mathrm{J}$ treatment farmlets and at the lower CSR.

In previous studies (Macdonald et al., 2008a; McCarthy et al., 2016), pasture DM production increased with stocking rate, such that actual CSR did not increase by as much as predicted. This is inconsistent with the results presented here. The most plausible reason for this inconsistency is that there was a negative effect of the CSR100 treatment on postgrazing residuals (Table 1) and that this had a negative effect on subsequent pasture production (i.e., overgrazing occurred). Lee et al. (2009) reported that repetitive severe depletion and failure to allow sufficient time for replenishment of plant NSC between grazing events leads to a reduction in regrowth of pasture. Postgrazing residual results presented in Table 1 reflect a more severe grazing severity by the HF cows and in the higher CSR farmlets. Postgrazing residuals were $251 \mathrm{~kg}$ of $\mathrm{DM} /$ ha less in the CSR100 farmlet paddocks than in the CSR80 farmlet paddocks and $100 \mathrm{~kg}$ of $\mathrm{DM} /$ ha less on the HF farmlet paddocks than on the $\mathrm{J}$ farmlet paddocks. Nonstructural carbohydrates are a stored energy reserve and provide energy for regrowth of pasture when the photosynthetic centers of the plant (i.e., the leaves) have been removed following grazing. Even if plants are allowed to recover to the 3-leaf stage of regrowth before the next defoliation, successive severe defoliations (i.e., $<40 \mathrm{~mm}$ ) have been reported to impair NSC synthesis and reduce storage during the regrowth period; this results in less herbage regrowth (Lee et al., 2009).

However, although the effect of CSR on pasture DM production in this experiment and the lack of consistency with previous studies is important, the interaction between breed and CSR $(P<0.05)$ in the pasture production variables measured is of particular interest. In fact, the negative effect of CSR on pasture DM production in this study was a direct result of the $17 \%$ reduction in pasture DM production in the HF-CSR100 treatment. As a result of this interaction in pasture DM production, there was a breed $\times$ CSR interaction 
Table 1. Effect of dairy cow breed [Jersey (J) and Holstein-Friesian (HF)] and comparative stocking rate ${ }^{1}$ (CSR; $80 \mathrm{or} 100 \mathrm{~kg}$ of BW/t of feed $\mathrm{DM}$ ) on average pasture DM yield during each season ${ }^{2}$ and annually, amount of pasture conserved as silage in each farmlet, average amount of pasture on each farmlet during each season (pasture cover), and pre- and postgrazing pasture mass during each season

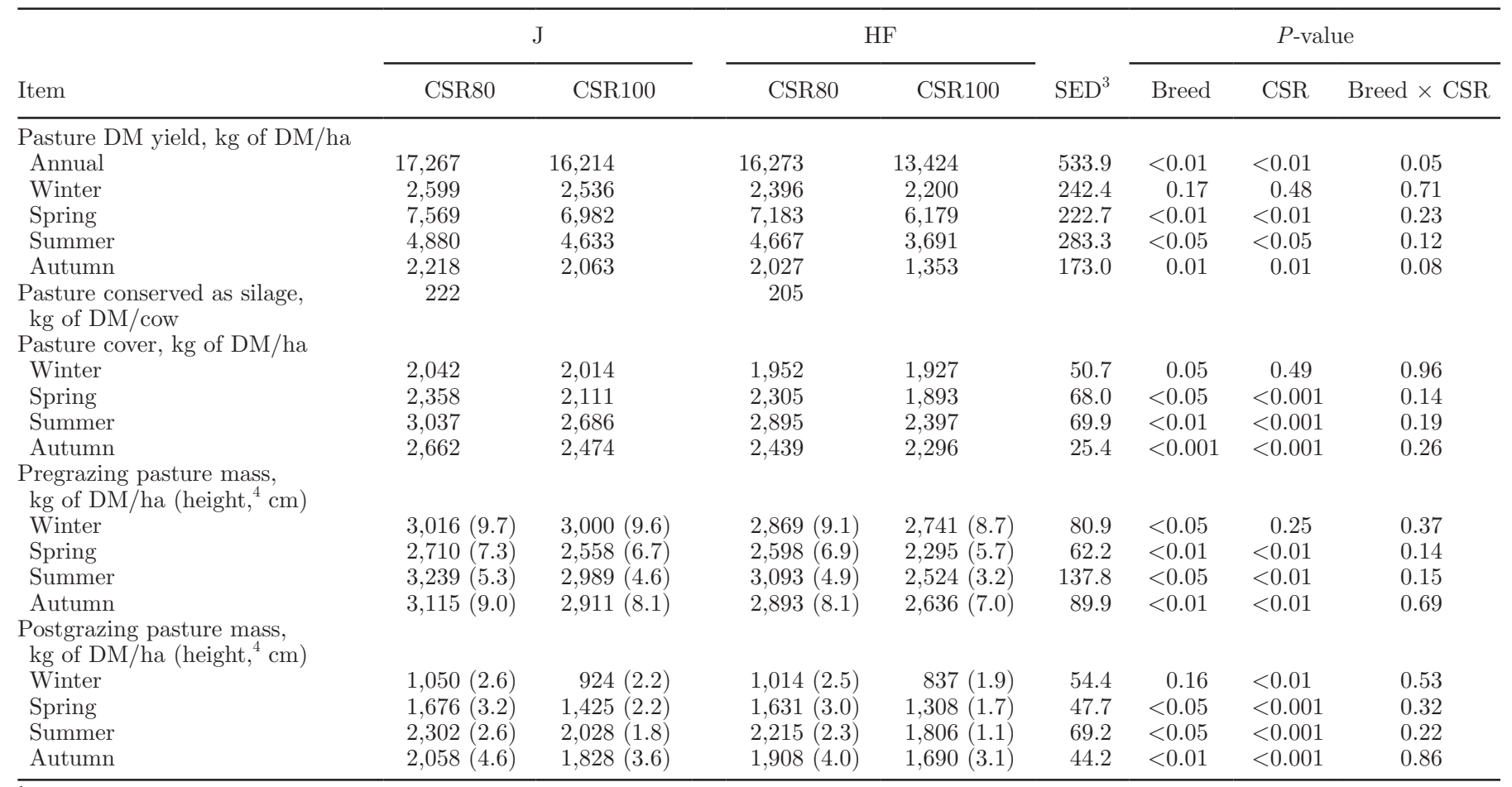

${ }^{1}$ Comparative stocking rate is a more complete measure of stocking rate and, therefore, feed allowance per cow; it accounts for the number of cows per hectare (i.e., stocking rate), the BW of the cow (i.e., as a proxy for milk production potential), the pasture producing potential of the farm ( $t$ of pasture $\mathrm{DM} / \mathrm{ha}$ ), the amount of supplement imported from off the farm ( $\mathrm{t}$ of $\mathrm{DM} / \mathrm{ha}$ ), and whether replacement stock are reared on the farm or on land remote from the milking platform (CSR $=\mathrm{kg}$ of BW/t of feed DM allowance; Macdonald et al., 2008a).

${ }^{2}$ Winter = June, July, August; spring = September, October, November; summer = December, January, February; autumn = March, April, May ${ }^{3}$ Standard error of the difference.

${ }^{4}$ Estimated pasture compressed height, back calculated from regression equations derived for this research farm.

for pasture harvested per cow and DMI per cow and for the milk production variables presented in Table 2 . The HF cows harvested $12 \%$ more pasture per cow in the CSR80 treatment but were unable to harvest any additional pasture DM per cow in the CSR100 farmlet. These results indicate that HF cows have a greater drive to eat than $\mathrm{J}$ cows.

The greater drive to eat due to the greater total ME requirements per cow (Table 3), as was evidenced in the CSR80 treatment, caused the more severe grazing defoliation in the HF-CSR100 treatment that is evident from postgrazing residuals presented in Table 1. This effect of breed was reported by L'Huillier et al. (1988), with HF cows grazing $0.3 \mathrm{~cm}$ lower than J cows offered a similar allowance. Estimated pasture height from reverse-engineered calibration equations indicate that $\mathrm{HF}$ cows grazed $0.1,0.2,0.3$, and $0.6 \mathrm{~cm}$ lower than $\mathrm{J}$ cows in winter, spring, summer, and autumn, respectively, in the CSR 80 treatment and $0.3,0.5,0.7$, and $0.5 \mathrm{~cm}$ lower, respectively, in the CSR100 treatment (Figure $1)$. So, with less feed available and already lower post- grazing residuals in the high-CSR treatment, HF cows grazed even lower at the higher CSR (Table 1). The lower grazing residual under the same allowance would be expected to reduce the regrowth of pasture (Lee et al., 2009), particularly at the postgrazing residual height estimated (i.e., $1.1 \mathrm{~cm}$ in summer), and result in a cycle of more severe subsequent grazing defoliations. This interaction between breed and CSR compounded, with the lower postgrazing residual resulting in a lower pregrazing mass in subsequent grazing events (Table 1), which resulted in a more severe grazing and a lower pregrazing mass subsequently, and so on, reducing annual and seasonal DM production in the current study. These results confirm the effect of breed reported by L'Huillier et al. (1988) and indicate that the effects of CSR on pasture production are not consistent across breeds and that J cows are more suitable to high stocking rates and high CSR than HF cows.

In support of this greater drive to eat in $\mathrm{HF}$ cows in the current study, Bryant et al. (2008) suggested that nutrients are allocated to particular functions in 
Table 2. Effect of dairy cow breed [Jersey $(\mathrm{J})$ and Holstein-Friesian (HF)] and comparative stocking rate ${ }^{1}$ (CSR; 80 or $100 \mathrm{~kg}$ of BW/t of feed DM) on lactation length, pasture disappearance, estimated DMI (i.e., pasture disappearance), annual milk production, average milk composition, BW and BCS 1 mo precalving and 1 wk postcalving, and calf birth weight

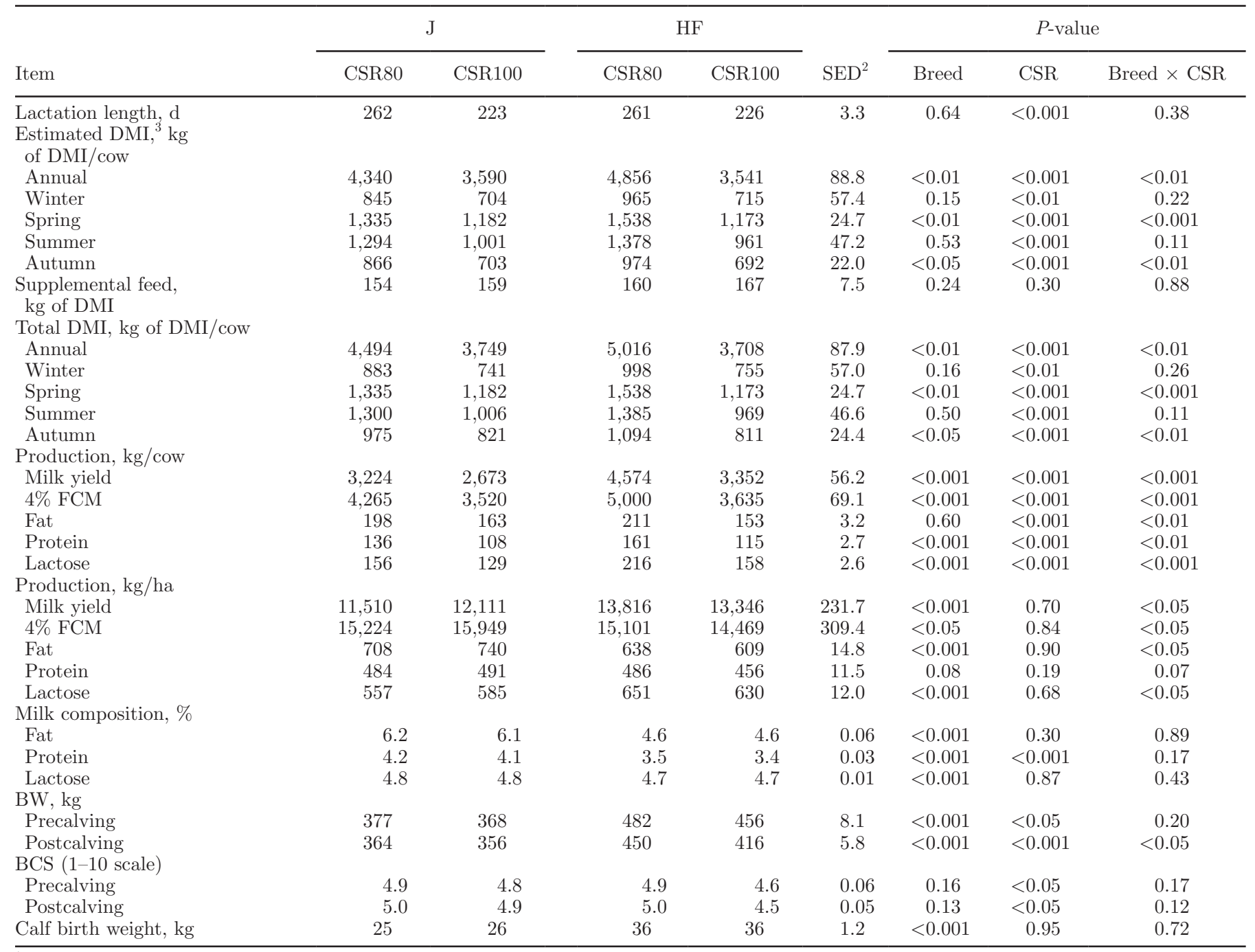

${ }^{1}$ Comparative stocking rate is a more complete measure of stocking rate and, therefore, feed allowance per cow; it accounts for the number of cows per hectare (i.e., stocking rate), the BW of the cow (i.e., as a proxy for milk production potential), the pasture producing potential of the farm ( $\mathrm{t}$ of pasture $\mathrm{DM} / \mathrm{ha}$ ), the amount of supplement imported from off the farm ( $\mathrm{t}$ of $\mathrm{DM} / \mathrm{ha}$ ), and whether replacement stock are reared on the farm or on land remote from the milking platform (CSR $=\mathrm{kg}$ of BW/t of feed DM allowance; Macdonald et al., 2008a).

${ }^{2}$ Standard error of the difference.

${ }^{3}$ Winter $=$ June, July, August; spring = September, October, November; summer = December, January, February; autumn = March, April, May.

a priority order: first maintenance, then pregnancy, lactation, growth, and fat deposition. Therefore, as proposed by Glazier (2002), when feed is scarce, body maintenance will take precedence over traits related to production, reproduction, or growth. As J cows have a lower per-cow maintenance requirement to satisfy than $\mathrm{HF}$, they could direct energy earlier in grazing events to milk production, maintenance of fat stores, or growth, reaching a point of satiation earlier. Therefore, when feed was scarce (i.e., at CSR100), grazing pressure was reduced earlier by J cows, accommodating pasture recovery through an earlier satiation of DMI.

\section{Milk Production}

Yields of milk, 4\% FCM, and milk components per cow were less at the higher CSR for both breeds. The effect of CSR on per-cow milk production $(P<0.001)$ is consistent with previous studies (Bryant et al., 1985; Macdonald et al., 2008a; McCarthy et al., 2010). Treatment effects reflect both a reduction in DMI per cow and a reduction in lactation length with increased stocking rate: lactation length was 39 and $35 \mathrm{~d}$ shorter in the CSR100 treatments for J and HF breeds, respectively. Reducing lactation length is a standard protocol 
Table 3. Effect of dairy cow breed [Jersey (J) and Holstein-Friesian (HF)] and comparative stocking rate ${ }^{1}$ (CSR; 80 or $100 \mathrm{~kg}$ of BW/t of feed $\mathrm{DM}$ ) on reproduction parameters

\begin{tabular}{|c|c|c|c|c|c|c|c|c|}
\hline Item & \multicolumn{2}{|c|}{$\mathrm{J}$} & \multicolumn{2}{|c|}{$\mathrm{HF}$} & $\mathrm{SED}^{2}$ & \multicolumn{3}{|c|}{$P$-value } \\
\hline Submission rate, ${ }^{4} \%$ & 97 & 96 & 98 & 89 & 3.5 & 0.25 & 0.07 & 0.15 \\
\hline Conception, $\%$ & 60 & 62 & 68 & 64 & 5.0 & 0.21 & 0.72 & 0.43 \\
\hline Services/conception & 1.6 & 1.6 & 1.5 & 1.5 & 0.12 & 0.36 & 0.94 & 0.88 \\
\hline
\end{tabular}

${ }^{1}$ Comparative stocking rate is a more complete measure of stocking rate and, therefore, feed allowance per cow; it accounts for the number of cows per hectare (i.e., stocking rate), the BW of the cow (i.e., as a proxy for milk production potential), the pasture producing potential of the farm ( $\mathrm{t}$ of pasture $\mathrm{DM} / \mathrm{ha}$ ), the amount of supplement imported from off the farm ( $\mathrm{t}$ of $\mathrm{DM} / \mathrm{ha}$ ), and whether replacement stock are reared on the farm or on land remote from the milking platform $(\mathrm{CSR}=\mathrm{kg}$ of BW/t of feed DM allowance; Macdonald et al., 2008a).

${ }^{2}$ Standard error of the difference.

${ }^{3}$ Percentage of cows not detected in estrus at the beginning of the seasonal breeding period.

${ }^{4}$ Percentage of cows submitted for AI within the first $3 \mathrm{wk}$ of the seasonal calving period.

for balancing nutrient supply and demand at higher stocking rates in pasture-based systems that do not import supplementary feed (Macdonald et al., 2008a).

However, as with the pasture DM production measurements, there was a breed $\times$ CSR interaction for most of the per-cow $(P<0.01)$ and per-hectare $(P$ $<0.05)$ milk production variables measured. At a greater feed allowance, HF cows consumed more DM and produced more $4 \% \mathrm{FCM}$, fat, protein, and lactose per cow than J cows. However, they were unable to exploit these DMI and production advantages at the higher CSR. In short-term experiments, Prendiville et al. (2010) reported that HF cows had a 14\% higher pasture DMI than their J counterparts (16.7 vs. $14.6 \mathrm{~kg} / \mathrm{d}$, respectively), and L'Huillier et al. (1988) established that HF cows consumed $13 \%$ more than J cows.

When the entire lactation was accounted for in the experiment reported here, HF cows consumed, on average, $20 \%$ more DM than J cows at the CSR80 and produced $17 \%$ more $4 \%$ FCM. The breed effects on milk yield and yield of fat and protein at CSR80 are consistent with the predicted differences in genetic merit for these traits: HF produced 1,350 kg more milk, $13 \mathrm{~kg}$ more fat, and $25 \mathrm{~kg}$ more protein than J cows at CSR80, and the genetic predicted difference for these traits was $1,144,13.4$, and $28.9 \mathrm{~kg}$, respectively. In comparison, however, at CSR100, estimated cow DMI was not affected by breed (Table 2), and HF cows produced only $679 \mathrm{~kg}$ more milk, $10 \mathrm{~kg}$ more fat, and $7 \mathrm{~kg}$ more protein than J cows, or 41,25 , and $76 \%$ less than the genetic predicted differences for these traits (breed $x$ CSR interaction; $P<0.001$ ). Our results highlight the effect of feed allowance on the ability of cows to achieve their genetic potential.

The interaction between breed and CSR on milk production variables is consistent with the treatment interactions on pasture production and supports the previous reports of Bryant et al. (2006, 2007) and Fulkerson et al. (2008). Utilizing a national genetic evaluation data set of approximately 185,000 lactations, Bryant et al. $(2006,2007)$ identified an interaction between feed allowance and cow breed in first-lactation animals. In their analysis, the milk production superiority of North American HF cows relative to New Zealand HF and $\mathrm{J}$ cows increased in dairy herds with higher average milk production. Similarly, Fulkerson et al. (2008) reported that the genetic predicted difference within the HF breed was achieved only when grazing cows were offered in excess of $800 \mathrm{~kg}$ of DM of a concentrate supplement/yr in addition to their pasture allowance (i.e., lower CSR).

On a per-hectare basis, the $\mathrm{J}$ cows harvested more pasture $(\sim 1 \mathrm{t}$ of $\mathrm{DM})$ and produced more milk fat at CSR80 but the same amount of $4 \%$ FCM and milk protein. In comparison, at CSR100, the J cows harvested $>2 \mathrm{t}$ of DM pasture/ha more than the HF cows and produced almost 1,480 kg more 4\% FCM and 131 and $35 \mathrm{~kg}$ more milk fat and protein/ha, respectively, than the HF-CSR100 treatment.

In summary, milk production per hectare was not affected by breed at CSR80, but per-cow production was greater in the HF breed. There was a significant pasture production and milk production per hectare advantage of the $\mathrm{J}$ breed in the CSR100 treatment despite lower milk production per cow. The results indicate that (1) the ability of a cow to achieve potential production over genetically inferior herd-mates is dependent on CSR; (2) the J breed is more suited than the HF breed to systems in which feed is limited; and (3) in systems in which feed is less limited, the HF cow is able to capitalize on its greater frame size and evident drive to eat (L'Huillier et al., 1988), increasing DMI per lactation 
and achieving the genetic predicted difference for milk production traits.

\section{$B W$ and $B C S$}

The effect of breed and CSR on BW and BCS preand postcalving is presented in Table 2. Jersey and CSR100 cows were lighter (lower BW) than HF and CSR80 cows, but cow BCS was not affected by breed. The CSR100 cows had lower BCS pre- and postcalving, which is consistent with the reported profile of BCS change associated with changes in stocking rate (Roche et al., 2007).

Interestingly, though, there was also an interaction between breed and CSR in postcalving BW $(P<0.05)$ and a consistent tendency $(P<0.15)$ for an interaction in pre- and postcalving BCS. This interaction reflects a failure of the HF breed to achieve calving BCS targets at high stocking rates (Roche et al., 2009), even when managed under the same management decision rules as the $\mathrm{J}$ breed. The 0.3- to 0.4-unit difference in BCS between HF-CSR80 and HF-CSR100 is consistent with
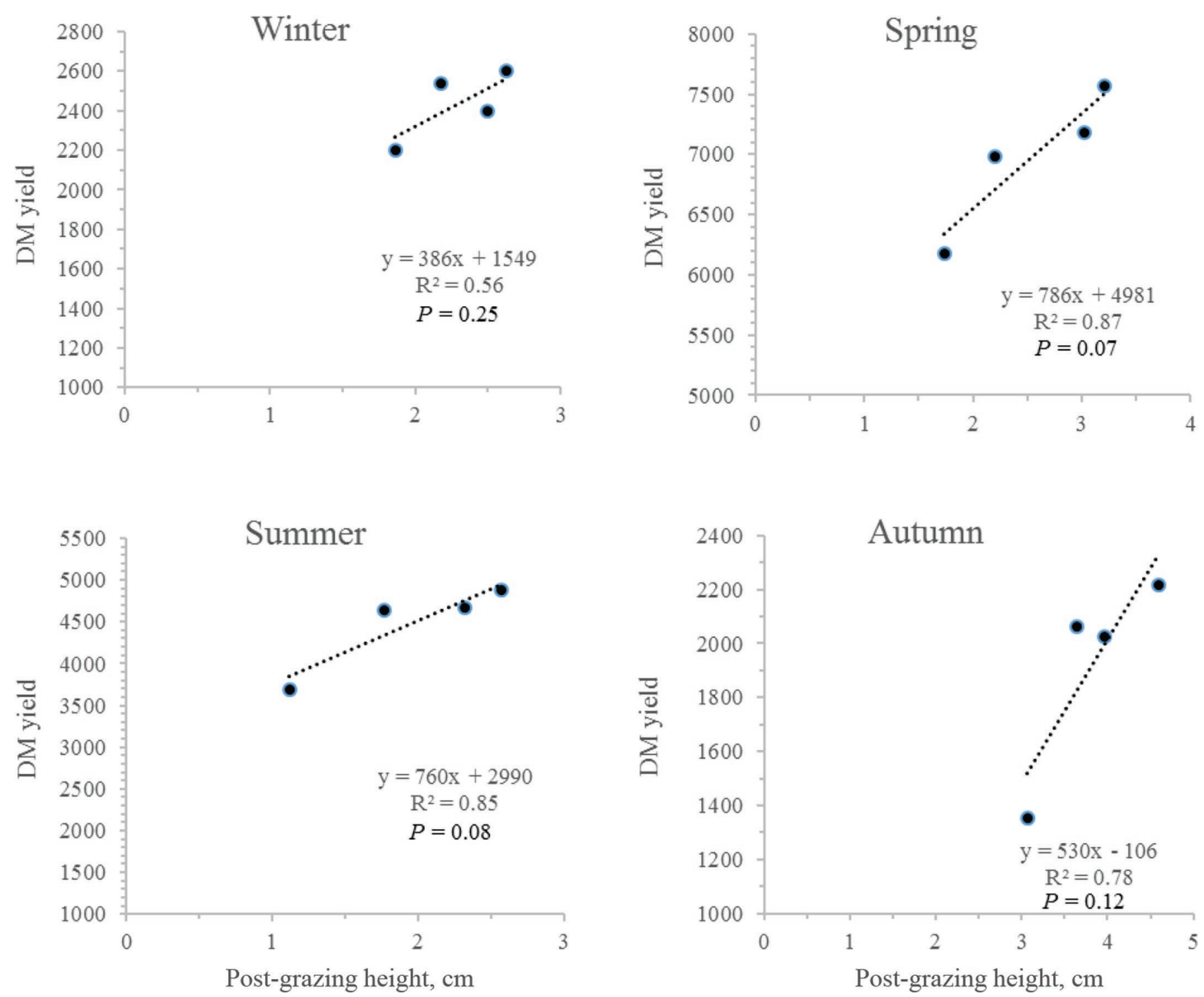

Figure 1. Relationship between average compressed postgrazing residual height $(\mathrm{cm})$ and average pasture DM yield (kg) per hectare for the season. Winter $=$ June to August; spring $=$ September to November; summer = December to February; autumn = March to May. Postgrazing residual heights were reverse calculated from regression equations produced for each season on this research farm over 3 yr. Color version available online. 
the difference of 0.5 BCS unit reported by Roche et al. (2007) for similar differences in CSR in HF cows. In contrast, the J cows managed to achieve the BCS targets. The reason for the interaction probably reflects differences in BW per BCS unit (Berry et al., 2006), the previously discussed interaction between breed and CSR in annual pasture DM yield, greater maintenance requirements in $\mathrm{HF}$ cows, or, possibly, greater $\mathrm{FCE}$ of the $\mathrm{J}$ described in many studies (L'Huillier et al., 1988; White et al., 2001; Prendiville et al., 2009, 2010; Beecher et al., 2014). Irrespective, it highlights an advantage of the $\mathrm{J}$ cows in maintaining a biologically sustainable grazing system at a high CSR.

\section{Reproduction Variables}

The effects of breed and CSR on reproduction variables are presented in Table 3. Even though animal numbers per treatment are small, there were noteworthy effects of breed and CSR on reproduction variables measured. The number of DIM to the first observed heat was greater $(P<0.001)$ in the HF breed and was greater in the HF-CSR100 group than in the HF-CSR80 group, but CSR did not affect DIM to first observed heat in the $\mathrm{J}$ treatment (breed $\times$ CSR interaction; $P$ $<0.05$ ). These results are consistent with the numerical increase in the percentage of HF cows recorded as anestrous at the planned start of the seasonal breeding period in the highest CSR treatment reported by Macdonald et al. (2008a), and it resulted in a tendency $(P=0.07)$ for a negative effect of CSR on submission rate in the current study. The effect of these 2 breeds on length of the postpartum anestrous period was also reported by Fonseca et al. (1983); they reported that J cows had a shorter interval from calving to first estrus than HF cows $(37.2 \pm 27.3$ and $66.9 \pm 33.9 \mathrm{~d}$, respectively). There were no significant effects of breed or CSR on any other reproduction variables measured.

\section{Energy Requirements}

Estimated ME requirements for maintenance, activity, pregnancy, BCS change, and production are presented in Table 4 . On a per-cow basis, $\mathrm{J}$ cows required less $(P$ $<0.05) \mathrm{ME}$ for all activities, with the exception of BCS change. In this study, J cows had a $14 \%$ lower $\mathrm{BW}^{0.75}$ compared with HF cows and would be expected to have a commensurate reduction in maintenance and activity ME requirements. This assumption is consistent with recent slaughter studies undertaken by Beecher et al. (2014), who reported that for a $27 \%$ lower $\mathrm{BW}^{0.75}$, the $\mathrm{J}$ cows in their study had a $24 \%$ lighter gastrointestinal tract and liver than HF cows - all factors expected to reduce maintenance $\mathrm{ME}$ requirements per cow in line with $\mathrm{BW}^{0.75}$. Similarly, the lighter calf birth weight (Table 2 ) in the $\mathrm{J}$ cows resulted in a $30 \%$ reduction in $\mathrm{ME}$ requirements per cow for pregnancy.

At CSR100, each cow required less ME per cow $(P$ $<0.01$ ) for maintenance, activity, change in BCS, and milk production because of the lower $\mathrm{BW}$ and milk production compared with the CSR 80 treatment cows. However, in contrast, when considered on a per-hectare basis, there was a greater $(P<0.01)$ requirement for $\mathrm{ME}(\mathrm{MJ} / \mathrm{ha})$ for maintenance, activity, pregnancy, and BCS change in the CSR100 treatments.

Per hectare, J cows required more ME for maintenance, activity, and production because of the greater number of cows and $\mathrm{BW}^{0.75}$ per hectare. Despite this, ME requirements for pregnancy per hectare were still 20 to $25 \%$ less for J cows than for HF cows. Metabolizable energy required for milk production per hectare was not affected by CSR, although there was a tendency $(P=0.11)$ for a breed $\times$ CSR interaction for ME requirements for production consistent with the previously discussed interaction in $4 \% \mathrm{FCM}$.

Crude measures of system-level efficiency of ME use (e.g., MJ of ME required to produce $1 \mathrm{~kg}$ of $4 \% \mathrm{FCM}$ ) can be deduced from the results presented in Tables 2 and 4. At CSR80, both J and HF cows required $10 \mathrm{MJ}$ of $\mathrm{ME} / \mathrm{kg}$ of $4 \% \mathrm{FCM}$ produced. However, $\mathrm{J}$ and $\mathrm{HF}$ cows required 128 and $133 \mathrm{MJ}$ of $\mathrm{ME} / \mathrm{kg}$ of fat and protein produced, respectively, signifying a $4 \%$ greater efficiency in the $\mathrm{J}$ cow at the low CSR for converting total ME intake to saleable product in a component pricing system. In comparison, at CSR100, HF cows required $6 \%$ more $\mathrm{ME} / \mathrm{kg}$ of $4 \% \mathrm{FCM}$ and $10 \%$ more $\mathrm{ME} / \mathrm{kg}$ of fat and protein, respectively, than their $\mathrm{J}$ comparison. This greater efficiency of ME use, particularly at CSR100, was also reflected at the per-hectare level, and these results are consistent with previous studies. For example, Prendiville et al. (2009) reported that J cows required 11\% less DMI during lactation for every kilogram of fat and protein produced, and Beecher et al. (2014) reported that DM digestibility, OM digestibility, $\mathrm{N}$ digestibility, NDF digestibility, and ADF digestibility were 2.2, 2.7, 3.2, 3.0, and $5.5 \%$ greater in J cows compared with HF cows, respectively. This equated to an $8 \%$ greater conversion of net energy intake to milk fat and protein. L'Huillier et al. (1988) also reported a breed effect in the utilization of $\mathrm{ME}$ in respiratory chambers. They reported a $25 \%$ reduction in the ME lost as heat in J cows, providing a possible reason for the breed efficiency differences estimated in the current study and in Prendiville et al. (2009) and Beecher et al. (2014). Irrespective of the reason, the results of a multiyear, system-level experiment presented here and recent component experiments indicate that the $\mathrm{J}$ breed has a significant advantage in the conver- 
sion of ME to 4\% FCM and milk components in grazing systems, especially when feed allowance is constrained at higher CSR.

\section{Economic Modeling}

The modeled effects of cow breed and CSR on the revenue, expenses, and operating profit of grazing dairy farms are presented in Table 5 and Supplemental Table S1 (https://doi.org/10.3168/jds.2017-14032). Gross farm revenue was greater for the $\mathrm{J}$ treatments and increased marginally with CSR in the $\mathrm{J}$ breed but declined by an equivalent amount in the HF breed between CSR80 and CSR100. Because of the greater cows per hectare and the assumption that labor is primarily associated with each animal (see Supplemental Table 1, https://doi.org/10.3168/jds.2017-14032; Macdonald et al., 2011), labor expenses were greater in the $\mathrm{J}$ breed compared with the HF breed and in the CSR100 treatment compared with the CSR80 treatment. Similarly, total stock expenses and total feed expenses were greater for the $\mathrm{J}$ treatment because of the greater cows per hectare at the same CSR and were greater at CSR100 than at CSR80. Other farm working expenses and overheads were also greater in the J breed and CSR100 treatments compared with the HF breed and CSR80 treatments, respectively, reflecting the additional costs associated with more cows per hectare. As a result, operating expenses per hectare were greater for J cows and CSR100 treatments compared with HF cows and CSR80 treatments, respectively.

Operating profit per hectare, which was calculated as the difference between gross farm revenue per hectare and operating expenses per hectare, was less at CSR100 than CSR80 irrespective of cow breed, but there appeared to be a breed $\times$ CSR interaction. Operating profit was $5 \%$ greater for the HF breed at CSR80 (NZ $\$ 3,505$ compared with NZ\$3,336) but was $15 \%$ less at CSR100 (NZ $\$ 2,490$ vs. $\$ 2,875$ ). The effect of CSR on operating profit is consistent with the previous economic assessment of stocking rate and CSR by Macdonald et al. (2011). They reported that operating profit per hectare declined by $11 \%$ for an equivalent increase in CSR in HF cows. In the HF and J breeds in the current study, operating profit per hectare was 29 and $14 \%$ lower, respectively, in the CSR100 treatment compared with CSR80. The economic modeling confirms that increasing CSR from 80 to 100 reduces operating profit per hectare in a pasture-based system not importing feed from off farm. However, the effect is much greater in HF cows than in $\mathrm{J}$ cows.

\section{CONCLUSIONS}

There was an interaction between breed and CSR in pasture and animal production variables measured. At the higher CSR, the HF treatment farmlet produced less pasture, probably because of persistent overgrazing,

Table 4. Effect of dairy cow breed [Jersey $(\mathrm{J})$ and Holstein-Friesian (HF)] and comparative stocking rate ${ }^{1}$ (CSR; 80 or $100 \mathrm{~kg}$ of BW/t of feed $\mathrm{DM})$ on the ME required ${ }^{2}$ for maintenance (MEm), activity (MEa), pregnancy (MEpg), change in BCS, and production (MEpr)

\begin{tabular}{|c|c|c|c|c|c|c|c|c|}
\hline Item & \multicolumn{2}{|c|}{$\mathrm{J}$} & \multicolumn{2}{|c|}{$\mathrm{HF}$} & $\mathrm{SED}^{3}$ & \multicolumn{3}{|c|}{$P$-value } \\
\hline \multicolumn{9}{|c|}{ ME required, MJ/cow } \\
\hline $\mathrm{MEa}$ & 1,435 & 1,212 & 1,528 & 1,213 & 20.0 & $<0.05$ & $<0.001$ & $<0.05$ \\
\hline MEpg & 1,373 & 1,388 & 1,962 & 1,942 & 63.7 & $<0.001$ & 0.95 & 0.72 \\
\hline BCS change & 330 & 636 & 318 & 832 & 136.6 & 0.38 & $<0.01$ & 0.32 \\
\hline \multicolumn{9}{|c|}{ ME required, MJ/ha } \\
\hline MEm & 62,834 & 74,420 & 61,283 & 75,278 & 974.1 & 0.63 & $<0.001$ & 0.13 \\
\hline MEa & 5,167 & 5,455 & 4,585 & 4,853 & 73.2 & $<0.001$ & $<0.01$ & 0.85 \\
\hline MEpg & 4,944 & 6,245 & 5,885 & 7,767 & 228.0 & $<0.001$ & $<0.001$ & 0.12 \\
\hline BCS change & 1,186 & 2,862 & 953 & 3,328 & 612.4 & 0.80 & $<0.01$ & 0.45 \\
\hline MEpr & 78,009 & 79,902 & 75,218 & 72,557 & $1,664.0$ & $<0.01$ & 0.73 & 0.11 \\
\hline Total ME & 152,230 & 168,884 & 147,923 & 163,783 & $1,834.4$ & $<0.01$ & $<0.001$ & 0.77 \\
\hline
\end{tabular}

${ }^{1}$ Comparative stocking rate is a more complete measure of stocking rate and, therefore, feed allowance per cow; it accounts for the number of cows per hectare (i.e., stocking rate), the BW of the cow (i.e., as a proxy for milk production potential), the pasture producing potential of the farm ( $\mathrm{t}$ of pasture $\mathrm{DM} / \mathrm{ha})$, the amount of supplement imported from off the farm ( $\mathrm{t}$ of $\mathrm{DM} / \mathrm{ha}$ ), and whether replacement stock are reared on the farm or on land remote from the milking platform (CSR $=\mathrm{kg}$ of BW/t of feed DM allowance; Macdonald et al., 2008a).

${ }^{2}$ Energy required was calculated using equations by Primary Industries Standing Committee (2007); see Supplemental Material (https://doi. org/10.3168/jds.2017-14032).

${ }^{3}$ Standard error of the difference. 
Table 5. Effect of dairy cow breed [Jersey $(\mathrm{J})$ and Holstein-Friesian $(\mathrm{HF})]$ and comparative stocking rate ${ }^{1}$ (CSR; 80 or $100 \mathrm{~kg}$ of $\mathrm{BW} / \mathrm{t}$ of feed $\mathrm{DM}$ ) on gross revenue, operating expenses, operating profit, ${ }^{2}$ and cost of production (all in NZ\$)

\begin{tabular}{|c|c|c|c|c|}
\hline \multirow[b]{2}{*}{ Item } & \multicolumn{2}{|c|}{$\mathrm{J}$} & \multicolumn{2}{|c|}{$\mathrm{HF}$} \\
\hline & CSR80 & CSR100 & CSR 80 & CSR 100 \\
\hline Milk price $^{3}$ & 5.88 & 5.85 & 5.97 & 5.96 \\
\hline Revenue & & & & \\
\hline Gross farm revenue & 7,522 & 7,767 & 7,216 & 7,005 \\
\hline Expenses & & & & \\
\hline Total labor expenses & 1,314 & 1,602 & 1,122 & 1,442 \\
\hline Total stock expenses & 725 & 888 & 621 & 802 \\
\hline Total feed expenses & 315 & 394 & 249 & 361 \\
\hline Total other working expenses & 1,151 & 1,256 & 1,081 & 1,197 \\
\hline Total overheads & 682.4 & 751.0 & 636.6 & 712.9 \\
\hline Total dairy operating expenses & 4,186 & 4,891 & 3,710 & 4,515 \\
\hline Dairy operating profit & 3,336 & 2,876 & 3,505 & 2,490 \\
\hline Expenses, cost $/ \mathrm{kg}$ of FCM & 0.27 & 0.31 & 0.25 & 0.31 \\
\hline Expenses, cost $/ \mathrm{kg}$ of fat and protein & 3.51 & 3.97 & 3.29 & 4.24 \\
\hline
\end{tabular}

${ }^{1}$ Comparative stocking rate is a more complete measure of stocking rate and, therefore, feed allowance per cow; it accounts for the number of cows per hectare (i.e., stocking rate), the BW of the cow (i.e., as a proxy for milk production potential), the pasture producing potential of the farm ( $t$ of pasture $\mathrm{DM} / \mathrm{ha}$ ), the amount of supplement imported from off the farm ( $\mathrm{t}$ of $\mathrm{DM} / \mathrm{ha}$ ), and whether replacement stock are reared on the farm or on land remote from the milking platform $(\mathrm{CSR}=\mathrm{kg}$ of $\mathrm{BW} / \mathrm{t}$ of feed DM allowance; Macdonald et al., 2008a). ${ }^{2}$ Operating profit is the gross farm revenue less the operating expenses.

${ }^{3} \mathrm{Cost}(\mathrm{NZ} \$) / \mathrm{kg}$ of fat and protein supplied. It differs for each treatment because the value of protein differs from the value of fat in component-pricing markets. Therefore, if breed or stocking rate affect protein percentage or fat percentage, it will affect milk price.

and as a result produced less milk and milk components per hectare. This resulted in an interaction in the modeled operating profit per hectare, with the HF breed being marginally more profitable than the $\mathrm{J}$ breed at CSR80 but less profitable at CSR100. The results confirm the superior efficiency of use of ME consumed for milk production in the $\mathrm{J}$ cow, particularly at the high CSR.

\section{ACKNOWLEDGMENTS}

The authors acknowledge all the help afforded them by No. 2 Dairy staff (DairyNZ Inc., Hamilton, New Zealand) and the statistical expertise of B. Dow (DairyNZ, Hamilton, New Zealand). This work was funded by New Zealand Dairy Farmers through DairyNZ Inc.

\section{REFERENCES}

Barbano, D. M., J. M. Lynch, and J. R. Fleming. 1991. Direct and indirect determination of true protein-content of milk by Kjeldahl analysis - Collaborative study. J. Assoc. Off. Anal. Chem. 74:281-288.

Beecher, M., F. Buckley, S. M. Waters, T. M. Boland, D. EnriquezHidalgo, M. H. Deighton, M. O'Donovan, and E. Lewis. 2014. Gastrointestinal tract size, total-tract digestibility, and rumen microflora in different dairy cow genotypes. J. Dairy Sci. 97:3906-3917. https://doi.org/10.3168/jds.2013-7708.

Berry, D. P., K. A. Macdonald, J. W. Penno, and J. R. Roche. 2006. Association between body condition score and live weight in pas- ture-based Holstein-Friesian dairy cows. J. Dairy Res. 73:487-491. https://doi.org/10.1017/S0022029906002020.

Bryant, A. M., M. A. S. Cook, and K. A. Macdonald. 1985. Comparative dairy production of Jerseys and Friesians. Proc. N.Z. Soc. Anim. Prod. 45:7-11.

Bryant, J., N. Lopez-Villalobos, C. Holmes, J. Pryce, J. Rossi, and K. Macdonald. 2008. Development and evaluation of a pastoral simulation model that predicts dairy cattle performance based on animal genotype and environmental sensitivity information. Agric. Syst. 97:13-25. https://doi.org/10.1016/j.agsy.2007.10.007.

Bryant, J. R., N. López-Villalobos, J. E. Pryce, C. W. Holmes, and D. L. Johnson. 2006. Reaction norms used to quantify the responses of New Zealand dairy cattle of mixed breeds to nutritional environment. N.Z. J. Agric. Res. 49:371-381. https://doi.org/10.1080/ 00288233.2006.9513727.

Bryant, J. R., N. López-Villalobos, J. E. Pryce, C. W. Holmes, D. L. Johnson, and D. J. Garrick. 2007. Short communication: Effect of environment on the expression of breed and heterosis effects for production traits. J. Dairy Sci. 90:1548-1553. https://doi.org/10 .3168/jds.S0022-0302(07)71640-5.

Capper, J. L., R. A. Cady, and D. E. Bauman. 2009. The environmental impact of dairy production: 1944 compared with 2007. J. Anim. Sci. 87:2160-2167. https://doi.org/10.2527/jas.2009-1781.

Cliff, S. C., G. R. Morris, I. S. Hook, and K. L. MacMillan. 1995. Calving patterns in dairy heifers following single "set-time" inseminations and re-synchrony preceding second inseminations. Proc. N.Z. Soc. Anim. Prod. 55:70-71.

FAO (Food and Agriculture Organization of the United Nations). 2009. The State of Food and Agriculture 2009: Livestock in the Balance. FAO, Rome, Italy.

Fonseca, F. A., J. H. Britt, B. T. McDaniel, J. C. Wilk, and A. H. Rakes. 1983. Reproductive traits of Holsteins and Jerseys. Effects of age, milk yield, and clinical abnormalities on involution of cervix and uterus, ovulation, estrous cycles, detection of estrus, conception rate, and days open. J. Dairy Sci. 66:1128-1147. https://doi .org/10.3168/jds.S0022-0302(83)81910-9. 
Fulkerson, W. J., T. M. Davison, S. C. Garcia, G. Hough, M. E. Goddard, R. Dobos, and M. Blockey. 2008. Holstein-Friesian dairy cows under a predominantly grazing system: Interaction between genotype and environment. J. Dairy Sci. 91:826-839. https://doi .org/10.3168/jds.2007-0147.

Glazier, D. S. 2002. Resource-allocation rules and the heritability of traits. Evolution 56:1696-1700. https://doi.org/10.1111/j.0014 $-3820.2002 . t b 01481 . x$

Godfray, H. C. J., J. R. Beddington, I. R. Crute, L. Haddad, D. Lawrence, J. F. Muir, J. Pretty, S. Robinson, S. M. Thomas, and C. Toulmin. 2010. Food security: The challenge of feeding 9 billion people. Science 327:812-818. https://doi.org/10.1126/science .1185383 .

Horan, B., P. Dillon, P. Faverdin, L. Delaby, F. Buckley, and M. Rath. 2005. The interaction of strain of Holstein-Friesian cows and pasture-based feed systems on milk yield, body weight, and body condition score. J. Dairy Sci. 88:1231-1243. https://doi.org/10.3168/ jds.S0022-0302(05)72790-9.

International Organization for Standardization. 1987. Milk: Determination of fat content. Gravimetric method (reference method). ISO, Geneva, Switzerland.

Kolver, E. S., and L. D. Muller. 1998. Performance and nutrient intake of high producing Holstein cows consuming pasture or a total mixed ration. J. Dairy Sci. 81:1403-1411. https://doi.org/10.3168/ jds.S0022-0302(98)75704-2.

L'Huillier, P. J., C. R. Parr, and A. M. Bryant. 1988. Comparative performance and energy metabolism of Jerseys and Friesians in early-mid lactation. Proc. N.Z. Soc. Anim. Prod. 48:231-235.

Lee, J. M., D. J. Donaghy, P. Sathish, and J. R. Roche. 2009. Interaction between water-soluble carbohydrate reserves and defoliation severity on the regrowth of perennial ryegrass (Lolium perenne L.)dominant swards. Grass Forage Sci. 64:266-275. https://doi.org/ 10.1111/j.1365-2494.2009.00692.x.

Macdonald, K., and J. Penno. 1998. Management decision rules to optimise milksolids production on dairy farms. Proc. N.Z. Soc. Anim. Prod. 58:132-135.

Macdonald, K. A., D. Beca, J. W. Penno, J. A. S. Lancaster, and J. R. Roche. 2011. Short communication: Effect of stocking rate on the economics of pasture-based dairy farms. J. Dairy Sci. 94:25812586. https://doi.org/10.3168/jds.2010-3688.

Macdonald, K. A., J. W. Penno, J. A. S. Lancaster, A. M. Bryant, J. M. Kidd, and J. R. Roche. 2017. Production and economic responses to intensification of pasture-based dairy production systems. J. Dairy Sci. 100:6602-6619.

Macdonald, K. A., J. W. Penno, J. A. S. Lancaster, and J. R. Roche. 2008a. Effect of stocking rate on pasture production, milk production, and reproduction of dairy cows in pasture-based systems. J. Dairy Sci. 91:2151-2163. https://doi.org/10.3168/jds.2007-0630.

Macdonald, K. A., G. A. Verkerk, B. S. Thorrold, J. E. Pryce, J. W Penno, L. R. McNaughton, L. J. Burton, J. A. S. Lancaster, J. H. Williamson, and C. W. Holmes. 2008b. A comparison of three strains of Holstein-Friesian grazed on pasture and managed under different feed allowances. J. Dairy Sci. 91:1693-1707. https://doi .org $/ 10.3168 /$ jds.2007-0441

McCarthy, B., L. Delaby, K. M. Pierce, F. Journot, and B. Horan. 2010. A meta-analysis of the impact of stocking rate on the productivity of pasture-based milk production systems. Adv. Anim. Biosci. 1:148. https://doi.org/10.1017/S2040470010002918.

McCarthy, B., L. Delaby, K. M. Pierce, J. McCarthy, C. Fleming, A. Brennan, and B. Horan. 2016. The multi-year cumulative effects of alternative stocking rate and grazing management practices on pasture productivity and utilization efficiency. J. Dairy Sci. 99:3784-3797. https://doi.org/10.3168/jds.2015-9763.

McCarthy, J., L. Delaby, D. Hennessy, B. McCarthy, W. Ryan, K. M. Pierce, A. Brennan, and B. Horan. 2015. The effect of stocking rate on soil solution nitrate concentrations beneath a free-draining dairy production system in Ireland. J. Dairy Sci. 98:4211-4224. https://doi.org/10.3168/jds.2014-8693.
McDougall, S., C. R. Burke, N. B. Williamson, and K. L. MacMillan. 1995. The effect of stocking rate and breed on the period of postpartum anoestrum in grazing dairy cattle. Proc. N.Z. Soc. Anim. Prod. 55:236-238.

O'Donovan, M., P. Dillon, M. Rath, and G. Stakelum. 2002. A comparison of four methods of herbage mass estimation. Ir. J. Agric. Food Res. 41:17-27.

Prendiville, R., E. Lewis, K. M. Pierce, and F. Buckley. 2010. Comparative grazing behavior of lactating Holstein-Friesian, Jersey, and Jersey $\times$ Holstein-Friesian dairy cows and its association with intake capacity and production efficiency. J. Dairy Sci. 93:764-774. https://doi.org/10.3168/jds.2009-2659.

Prendiville, R., K. M. Pierce, and F. Buckley. 2009. An evaluation of production efficiencies among lactating Holstein-Friesian, Jersey, and Jersey $\times$ Holstein-Friesian cows at pasture. J. Dairy Sci 92:6176-6185. https://doi.org/10.3168/jds.2009-2292.

Primary Industries Standing Committee. 2007. Nutrient Requirements of Domesticated Ruminants. CSIRO, Clayton South, VIC, Australia.

Roche, J. R., and D. P. Berry, 2006. Periparturient climatic, animal, and management factors influencing the incidence of milk fever in grazing systems. J. Dairy Sci. 89:2775-2783. https://doi.org/10 .3168/jds.S0022-0302(06)72354-2.

Roche, J. R., D. P. Berry, A. M. Bryant, C. R. Burke, S. T. Butler, P. G. Dillon, D. J. Donaghy, B. Horan, K. A. Macdonald, and K. L. Macmillan. 2017a. A 100-year review: A century of change in temperate grazing dairy systems. J. Dairy Sci. 100:10189-10233. https://doi.org/10.3168/jds.2017-13182.

Roche, J. R.. D. P. Berry, J. M. Lee, K. A. Macdonald, and R. C. Boston. 2007. Describing the body condition score change between successive calvings: A novel strategy generalizable to diverse cohorts. J. Dairy Sci. 90:4378-4396. https://doi.org/10.3168/jds .2006-729

Roche, J. R., P. G. Dillon, C. R. Stockdale, L. H. Baumgard, and M. J. Vanbaale. 2004. Relationships among international body condition scoring systems. J. Dairy Sci. 87:3076-3079. https://doi.org/ 10.3168/jds.S0022-0302(04)73441-4.

Roche, J. R., N. C. Friggens, J. K. Kay, M. W. Fisher, K. J. Stafford, and D. P. Berry. 2009. Invited review: Body condition score and its association with dairy cow productivity, health, and welfare. J. Dairy Sci. 92:5769-5801. https://doi.org/10.3168/jds.2009-2431.

Roche, J. R., S. F. Ledgard, M. S. Sprosen, S. B. Lindsey, J. W. Penno, B. Horan, and K. A. Macdonald. 2016. Increased stocking rate and associated strategic dry-off decision rules reduced the amount of nitrate-N leached under grazing. J. Dairy Sci. 99:5916-5925. https://doi.org/10.3168/jds.2016-11024.

Roche, J. R., S. P. Washburn, D. P. Berry, D. J. Donaghy, and B. Horan. 2017b. Seasonal Pasture-Based Dairy Production Systems. 3rd ed. D. Beede, ed. American Dairy Science Association, Champaign, IL.

Sheahan, A. J., E. S. Kolver, and J. R. Roche. 2011. Genetic strain and diet effects on grazing behavior, pasture intake, and milk production. J. Dairy Sci. 94:3583-3591. https://doi.org/10.3168/jds .2010-4089.

Washburn, S. P., S. L. White, J. T. Green Jr., and G. A. Benson. 2002. Reproduction, mastitis, and body condition of seasonally calved Holstein and Jersey cows in confinement or pasture systems. J. Dairy Sci. 85:105-111.

White, S. L., G. A. Benson, S. P. Washburn, and J. T. Green. 2002. Milk production and economic measures in confinement or pasture systems using seasonally calved Holstein and Jersey cows. J. Dairy Sci. 85:95-104. https://doi.org/10.3168/jds.S0022-0302(02)74057 -5 .

White, S. L., J. A. Bertrand, M. R. Wade, S. P. Washburn, J. T. Green, and T. C. Jenkins. 2001. Comparison of fatty acid content of milk from Jersey and Holstein cows consuming pasture or a total mixed ration. J. Dairy Sci. 84:2295-2301. https://doi.org/10 .3168/jds.S0022-0302(01)74676-0. 